\title{
Analysis of Business Marketing Strategy in an Effort to Increase the Sales Volume of Company $X$ in Dili City, East Timor
}

\author{
Zonia Dos Reis Ferreira \\ School of Magister Management, Parahyangan Catholic University, Jl. Merdeka No.30, Bandung Indonesia
}

\begin{abstract}
This study proposed to analyze marketing strategies in an effort to increase the sales volume of Company X in Dili City, East Timor. The method used in this research is descriptive qualitative which shows to analyze the marketing mix strategy (Marketing Mix 4Ps) beer beverage products Company X in Dili City, Timor-Leste. The results show that the product strategy is to prioritize the quality (quality product) of the beer itself, the taste of the aroma and not cause disease and other physical disorders, and unique. Price strategy is the standard price of beer and according to the amount of alcoholic beer. Distribution Channel Strategy Company X collaborates with two large companies in Dili to distribute beer beverage products to 12 districs and in the city of Dili. Company X promotional strategies carry out promotional strategies through Event Sports, Live Music, department stores, convenient stores, agents, shops, social internet media (Facebook, Instagram and YouTube) and Advertising (Newspaper, Brochure, Magazine, LED (Light Emmiting Diode).
\end{abstract}

Keywords : Strategy of Marketing Mix (4Ps)

DOI: $10.7176 / \mathrm{EJBM} / 11-29-05$

Publication date:October $31^{\text {st }} 2019$

\section{Introduction}

Company $\mathrm{X}$ is one of the companies engaged in the production of beverages with the brand $\mathrm{ABC}$, Tiger and Bintang. Initially began signing a contract between the Government of Timor Leste and Company $\mathrm{X}$ in December 2015 and then continued construction. Company $\mathrm{X}$ is an organization that is relatively new for the first time in the beer beverage manufacturing industry located in Hera, Dili, Timor Leste. Company $\mathrm{X}$ is the result of investment from one of the large companies based in Singapore engaged in the production of beer drinks as well. Therefore, as a beverage production company beer have to know and understand the customers behavior basically and develop appropriate strategies and programs in order to take advantage of existing opportunities.

In this case of course, Company $\mathrm{X}$ requires the right marketing strategy to increase the number of products sold by Company X in the City of Dili, Timor-Leste. Therefore, researcher will analyze and knowing the marketing strategy carried out by Company $\mathrm{X}$ in increasing the sales volume of the products offered to consumers. Another important thing that must be considered is, if the determination of the marketing strategy is inappropriate, it can result in a decrease in profit, but if the strategy used is right, the company will get the maximum profit. Therefore, in determining the marketing strategy at Company $\mathrm{X}$, it is very necessary to assist in generating profit for selling beer products at Company X.

Marketing mix is one part of the marketing strategy, with this to convey information widely, introduce a product of goods and services, stimulate consumers to give even create personal preferences for the image of a product. The marketing mix strategy in question is Product, Price, Place and Promotion, which plays a major role in the increasingly fierce competition and the development of demand for goods. In this very tight competition situation, especially in the buyer's market, the role of pricing and sales promotion is very important especially to build customer commitment. Company $\mathrm{X}$ has provided products such as beer drink are $\mathrm{ABC}$, Tiger and Bintang (Products in the Local / Local Product) and Beer drinks in bottles of Heineken and Sagres (Foreign Products / International Product), with prices that are standard with do various activities in terms of promotion through social media and advertising, provide an easy place to access buying products. (Company X Internal Data: 2018).

The main problem faced by the Company $\mathrm{X}$ was the first, the competition between Beer products, for example ABC beverage products, Tiger, Bintang, Heineken and Sagress. With other beer drinks, for example, Red Label, Black Label, Super Bock, Orengboom, James Boag's premium lager and other brand drinks from Tasmania, Scotland and Portugal, which are still imported into Timor Leste. There are still many East Timorese people who are interested in buying beer drinks, so it is a bit of a hindrance for the Company to retain customers. (Source: Interview Manager Marketing PT. X: 2018). Secondly, the distribution channel (Place) of Heineken beer beverage products which only exists in Dili City and Sagres is only distributed in the capital city of Dili and 2 districts (Maliana and Baucau) while the other 10 Districts have not. Third, price (Price) is one of the problem factors in the company where the price sold from the company to resellers and resellers plays a price that is not the same as the basic selling price of the company. The fourth, promotion (promotion) of many other companies that also promote beverage products with other brands takes a little attention from customers but there are still many interested customers. Therefore, company $\mathrm{X}$ is still conducting surveys and analyzing good and appropriate marketing strategies so that it can attract the attention of customers to buy their products which are marketed 
through Resellers to all Districts in Timor Leste to increase sales volume to the Company X.

\section{Objective}

To analyze the marketing mix strategy (4Ps Marketing Mix) of Beer Company X beverage products in Dili City, Timor-Leste.

\section{Theory}

According to Kotler and Keller (2012: 5) states that marketing mix is a set of marketing tools that companies use to continuously achieve their marketing goals in their target markets. Marketing as a combination of activities that are interconnected to be able to find out what is needed by consumers, so companies can develop products, prices, services and do promotions in order to meet consumer needs and get profits. With marketing it will help consumers to determine the product needed based on certain factors such as quality, time of purchase, and place of purchase. In addition, consumers can be used as information to support appropriate marketing activities by business people. So with the right marketing it will be able to generate maximum revenue for the company.

3.1 According to Philip Kotler \& Kevin Lane Keller (2012: 4), providing a definition of a product is anything that can be offered into the market to be noticed, owned, used or consumed so that it can satisfy a desire or all needs. Products marketed include physical goods, services, experiences, events, people, places, property, organizations, and ideas. So that the product is something that can be offered on the market and can be used by customers / consumers well and also beneficial. Product strategy is the core of a marketing mix strategy where retailers can offer unique attributes that differentiate their products from their competitors. Quality, design, features, brand name and size characterize the product. product acceptance by customers is based on product quality and design.

3.2 According to Ferrell and Hartline (2014: 167-168), that basic pricing strategy, companies also use other techniques to adjust or exchange prices. This technique can involve permanent adjustments to product prices, or temporary adjustments that are used to stimulate sales during certain times or situations.

3.3 According to Goi (2011) and Muala \& Qurneh (2012) in the journal Muhammad (2014: 102) distribution strategy (distribution strategy) / place strategy requires effective distribution of company products among marketing channels such as wholesalers or retailers. The distribution system is the main external resource.

3.4 Kasmir and Jakfar (2012: 59) state that promotion is the most effective means to attract and retain consumers. There are several promotional strategies in disseminating information about company products, including advertising (advertising), personal sales (Personal Selling), sales promotion (Sales Promotion) and Publicity (Publicity). But in this study the authors use the description specifically on Advertising and Social Media Internet according to the company's internal data X.

\section{Methodology}

This study analyzes the marketing strategies of Company X in Dili City, East Timor using descriptive qualitative research methods. Primary data collected through interviewing the Marketing Manager and his staff. Then secondary data is taken from books, International Journal, and from public and private sector documents related to Company X.

\section{Result (Findings)}

Strategy Marketing MIX (4Ps) in Company X

\subsection{Product Strategy}

Company $\mathrm{X}$ has 5 brands that are marketed to consumers namely Heineken, Sagres, Bintang, Tiger and ABC. However, the Company's product strategy at this time, is focused on the three brand brands, namely Bintang, Tiger and $\mathrm{ABC}$ because this is a beverage that can already be produced in Timor Leste. The superiority of the product strategy of Beer from the Company X is the Quality of beer, the aroma of the aroma and does not cause disease and other physical disorders, has a size that fits the amount of $330 \mathrm{ml}$.

Table 5.1 Company X Products

\begin{tabular}{|c|c|c|c|}
\hline & & & \\
Brand & Type of Product & Alcohol content & Parent Country \\
\hline Heineken & Premium & $5.0 \%$ & Singapure \\
\hline Sagres & Premium & $5.0 \%$ & Portugal \\
\hline ABC & Mainstream & $6.8 \%$ & Timor Leste \\
\hline Bintang & Mainstream & $4.5 \%$ & Timor Leste \\
\hline Tiger & Mainstream & $4.5 \%$ & Timor Leste \\
\hline
\end{tabular}

(Sources: Internal Data Company X: 2018) 
Heineken: Premium beer with 5.0\% alcohol. The target group is working individuals, students and students with groups between the ages of 18-35 years. Sagres drinks are produced in Singapore and then imported into Timor Leste. According to the statistics of the Ministry of Finance of Timor Leste in 2018 with a total (supplementary unit of 87,162).

Sagres: Premium beer with 5.0\% alcohol. The target group is working individuals, students with groups between the ages of 18-35 years. Sagres drinks are produced in Portugal and then imported into Timor Leste.

According to the statistics of the Ministry of Finance of Timor Leste in 2018 with a total (supplementary unit of 34,730).

ABC: Mainstream beer with an alcohol amount of $6.8 \%$. The target group is working individuals and students with an age group between $35-40$ years in which education and income are at a moderate level and a majority of $90 \%$ of men consume ABC beer products. For now ABC Beer is produced by Company X (Interviewed: Heineken Timor: 2018)

Bintang: Mainstream beer with $4.5 \%$ alcohol. The target group is working individuals and students with groups between the ages of $18-35$. The majority of $70 \%$ of men who consume Bintang beer and $30 \%$ more for women also like Bintang beer. Now, beer Bintang $(330 \mathrm{ml}$ and $250 \mathrm{ml})$ is produced by Company X.

Tiger: It aims to be a global beer APB (Asia Pacific Breweries) distributed in Timor-Leste. Tiger is the most famous beer in Singapore that has been known for its good reputation. The Company X produces new $250 \mathrm{ml}$ Tiger beer with $4.5 \%$ alcohol and has been marketed in several stores, supermarkets in Dili, Timor-Leste. Tiger beer is produced by Company $\mathrm{X}$.

\subsection{Price Strategy}

One of the main reasons why companies find it difficult to set prices for their products and services relates to the limited availability of information that might be obtained, but the relative difficulties that information about demand might obtain.

The company has principles in setting prices that take into account the following factors: (1) Production costs such as packaging costs, (2) Tax rates, (3) Marketing and Economic Situations and (4) Competitors. (Source: Interviewed: 2018)

The following is the price list of Beer products provided by the Lisun Timor Company and East Timor Trading can be seen in table 5.2 .

Table 5.2 The Price from Company Lisun Timor and East Timor Trading

\begin{tabular}{|c|c|c|c|}
\hline \multirow{2}{*}{ Brand Name } & Packaging & Size (ml) & Ratail Price (USD) \\
\hline \multicolumn{4}{|c|}{ PT. East Timor Trading } \\
\hline Heineken & Kaleng & $330 \mathrm{ml}$ & $\$ 1.65$ \\
\hline Heineken & Botol & $330 \mathrm{ml}$ & $\$ 2.00$ \\
\hline Sagres & Potol Lisun Timor & $\$ 1.50$ \\
\hline Sagres Mini & Botol & $250 \mathrm{ml}$ & $\$ 1.25$ \\
\hline ABC & Kaleng & $330 \mathrm{ml}$ & $\$ 1.40$ \\
\hline Bintang & Kaleng & $330 \mathrm{ml}$ & $\$ 1.25$ \\
\hline Tiger & Kaleng & $250 \mathrm{ml}$ & $\$ 1.00$ \\
\hline
\end{tabular}

(Sources : Internal Data Company Lisun Timor dan East Timor Trading: 2018)

The market selling price in Dili and District must be the same with each other but the profit margin added by the agent and shop must be around 5\% - 10\%. However, price and consumer behavior tend to have a controversial direction, in particular, during an economic slowdown, if there is an increase in beer prices, consumer behavior will definitely change, and customers will buy cheap beer. Therefore, Company X sets the price at which the price is not too expensive and also not too cheap according to the standard price of beer regulated by the government (Ministeriu Comerciu e Industria Timor Leste).

\subsection{Distribution Strategy}

The distribution of company X beverage product sales through 2 companies, namely the Lisun Timor Company and East Timor Trading where the Company X gives them credit based on the criteria that at the end of the second year the company must enter the amount of the sale of beer products according to the target both companies. Of the two companies, they are able to invest with a high amount of capital. Therefore, it will allow the two companies to buy enough products for their shares. Then the two companies carried out a distribution strategy by reselling through Reseller wholesalers or general shops, Bar \& Restaurant supermarkets, Hotels \& Resorts in Dili City. And also on customers can come directly to buy in both companies for activities or events (Wedding and Anniversary) with a sufficient number of lots for example 100 carton ie 50 carton beer Bintang, 20 carton ABC 
20 Carton Tiger and Sagres bottles 10 carton ( Source: Internal Data from Lisun Timor Company: 2018). According to the Company's Internal Data (Lisun Timor: 2018) that for now, the Company has distributed beer beverage products to 12 districts in Timor Leste. Because companies set up warehouses in 4 districts namely Baucau, Maliana, Oecusse and Covalima) and in Dili there are: 7 Lisun's salesman for alcohol category, also in Districts: 8 Lisun salesmen for mix category.

So that customers are easy to access buying beer drinks in the nearest shops. As for the Heineken beer beverage products, it is only distributed in the city of Dili because the stock is limited so that it is not distributed to other districts, because the beverage is targeted at the upper middle class with quite expensive prices.

\subsection{Promotion Strategy}

The objectives of the promotion carried out by company $\mathrm{X}$ are: (1) To provide information on beer products with better image quality like that of Heineken in other countries and have the right product positioning, (2) To approach the main target group (Customer) and, (3) To make memory like Heineken to the greatest level. Company X has a promotional strategy focused on three products, namely Bintang, Tiger and ABC through Event Sports, Music, department stores, convenient stores agents, shops, internet social media (Facebook, Instagram and YouTube) and Advertising. Because, the three products are produced in Timor Leste, therefore, the Company prioritizes promotion strategies on products in the country to disseminate information about beer beverage products, namely Heineken, Sagres, Bintang, ABC and Tiger to all customers to more easily access information about products provided by the company, so they can be interested in buying these products.

The following table 5.4. Description of the Company X promotion strategy.

\begin{tabular}{|c|l|}
\hline Produk PT.X & \multicolumn{1}{c|}{ Promotion } \\
\hline Bintang, Tiger and ABC & Promosi: \\
& • Event Sports: Sepak Bola dan Basket Ball.; \\
& - Tour de Timor, \\
& - Maraton dan \\
& - Live music (El Legendario) \\
& - Trade Incentive for agents, shops and consumers \\
& - Trade centers, department stores and convenient stores. \\
& Media Social: Facebook, Instagram dan Youtube. \\
& Advertising: Newspaper, Brosur, Magazine, LED (Light Emmiting \\
& Diode). \\
\hline
\end{tabular}

(Sources: Internal data Company X: 2018)

\section{Conclusion and Recommendation \\ 6.1 Conclusion}

According to the writing of this analysis on research, it can be concluded that the marketing mix strategy of Company $\mathrm{X}$ is as follows:

Product strategy: Company X product strategy is to determine the characteristics of a product or service that will meet customer needs. A product can be seen as a whole bundle of satisfaction offered by marketers to the market. The company responds to consumer needs by conducting research relative to the behavior of production, marketing, consumers, and general stores in sequence. And developing the quality and value of beer beverage products produced and expanding distribution channels to stores in 12 districts including the capital of Dili to increase the volume of beer beverage sales.

Price strategy: Criteria in setting marketing prices are used to be appropriate in consideration of consumer income, having criteria calculated as follows: (1) Beer production costs (2) Competitors (3) Marketing and economic situation and (4) Rates tax.

Distribution strategy: Company X cooperates (MoU / Memorandum of Understanding) with 2 large companies in Dili, namely: East Timor Trading and Lisun Timor to distribute the beer production. East Timor Trading company distributes Heineken beer products, while the Lisun Timor Company distributes Sagres, Bintang, $\mathrm{ABC}$ and Tiger beer products.

Promotion strategy: Company $\mathrm{X}$ conducts a promotional strategy through Event Sports, Live Music, department stores, convenient stores, agents, shops, social media internet (Facebook, Instagram and Youtube) and Advertising. So that it can provide a lot of information to customers to more easily access information about the products provided by the company.

\subsection{Recommendation}

Recommendations for the Company $\mathrm{X}$ regarding the marketing mix strategy (marketing mix) are as follows;

1. Products: Improve the quality of beer beverage products especially in the country, namely Bintang, ABC 
and Tiger beer so that it can foster customer / customer perceptions of the value of the quality of the product, then the customer can continue to buy and ultimately increase profits for company because the public already knows the quality of products and brands offered by the company for customers.

2. Price: Company X can maintain to set a standard price according to the amount of percent (\%) alcohol and milliliters $(\mathrm{ml})$ of the beer packaging. So that customers can feel that the price set by Company $\mathrm{X}$ is the right price and affordable.

3. Place: A strategic place is a very important thing for companies to market their products. Company X can take advantage of strategic places in the City of Dili and also in areas in several districts through shops to sell beer beverage products. So that, this strategy can increases the motivation of customers to buy beer products.

4. Promotion: The future program Company $\mathrm{X}$ can develop and provide information on beer beverage products (Heineken, Sagres, Tiger, ABC and Bintang) through fund distribution activities to repair small kiosks / shops, provide training for swords small to be able to market beer products well as a form of giving knowledge / knowledge to small swords. So that, in the customer's perception that the company is very helpful to traders in terms of trade. And then, this is part of the promotion of Company $\mathrm{X}$ in the future.

\section{References}

Ferrel, O. C. \& Hartline Michael D. (2014) "Marketing Strategy: Text and Cases", $6^{\text {th }}$ ed. South-Western, USA. Part 3 (Chapter 5,6,7); 115-214.

Kotler, Philip dan Keller, kevin L. (2012) "Marketing Management” $14^{\text {th }}$ Ed. Prentice hall, New Jersey. 4-5.

Khan, Muhammad T. (2014) “The Concept of 'Marketing Mix' and its Elements (A Conceptual Review Paper) International Journal of Information, Business and Management, Vol. 6, No.2. 95-103.

Kasmir dan Jakfar (2012) "Studi Kelayakan Bisnis" Edisi Revisi. Kencana: Jakarta. 59-60.

Sugiyono. (2018) "Metode Penelitian Kuantitatif, Kualitatif, dan R\&D” Bandung: CV Alfabeta. 87-88.

Sinee, Sankrusme (2013) "Marketing Strategy Analysis of Thai Asia Pasific Brewery Company" Journal International of Economic and Management Engineering; Vol:7 No;7. 2169-2174. 